WEDNESDAY, JUNE $25 \mathrm{TH}, 1879$.

The Hon. William Macleay, M.L.C., F.L.S., in the Chair.

W. H. Archer Esq., was elected a Member.

DONATIONS.

Journal of the Royal Microscopical Society, Vol. II., part 2.

Transactions of the Philosophical Society of Adelaide for 1877 -78 .

Native Plants of Victoria by Baron F. von Mueller, K.C.M.G.

\title{
PAPERS READ.
}

Notes on some Recently described Birds from the Solomon IsLANDS, with remarks on some Australian birds mentioned in Mr. R. B. Sharpe's Cat. of Bds., Vol. IV. By E. P. Ramsay, F.L.S., C.M.Z.S. \&c.

\section{Monarcha rufocastanea, Ramsay.}

Since describing this Flycatcher from the Solomon Islands, I find a note, in Sharpe's Cat. B. IV., p. 376. (just received) and a figure, relating to the $M$. castaneiventris of Verreaux; (Pomarea castaneiventris, of Sharpe's Cat. Vol. IV., p. 435.) although my species is very much smaller, it agrees well with Mr. Sharpe's description in coloration. It appears that this bird is only known in Europe by a single skin, in the British Museum, and the habitat given is "Oceania."

Ornithologists will be glad to learn the more definite habitat of this fine species, and also to know that it is by no means rare on the Island of "Gaudalcanar." This bird had hitherto been confounded with Myiagra castaneiventris, of Finsch and Hartlaub; 
(Fauna centralpolyn : p. 93.) which is quite a different bird, and which is identical with Myiagra vanikorensis, Cassin, U. S. Expl. Exped., p. 148. (See Sharpe's Cat. of Birds, Vol. IV., p. 376.)

\section{Graucalus solomonensis.}

Graucalus pusillus, Ramsay, P.L.S. of N.S.W., Vol. IV., p. 71.

As the species name "pusillus" has already been employed for more than one species of the Campophagide I propose to change the specific name of this bird as above.

It comes very near to $G$. lineatus, Swains, and $G$. maforensis, Meyer; but differs both in size and in the markings on the undersurface, but chiefly in the different coloration of the sexes.

\section{Macropygia rufocastanea, $s p$. nov.}

Macropygia, sp.; Ramsay, P. Linn. Soc. of N.S.W., Vol. IV. p. 73.

The whole of the upper and under surface of a rich deep cinnamon rufous, slightly paler on the throat. Primaries blackish, the inner webs of all margined with rufous at the base, feathers on the chest and sides of the neck slightly forked, their median portions black, and being but partly concealed gives to these parts a mottled appearance, a few feathers on the crown in some specimens, also showing their blackish partly concealed portions; an oblique subterminal ashy bar on the three outer feathers on either side of the tail, on the fourth feather the bar is more longitudinal and confined to the inner web, the remainder of the tail feathers uniform in tint with the body. Bill black, the tip reddish brown ; legs and feet orange red. Total length, 11.5 in. ; wing, 5.6 in. ; tail, 6.2 in. ; tarsus, 0.85 , middle toe, (s.u.) 0.8 ; hind toe, (s.u.) 0.4. Bill from forehead, 0.75 ; from gape, 0.73 ; from nostril, $0 \cdot 3$.

Hab. Solomon Islands.

This species comes near to $M$. nigrirostris of Salvadori, and $M$. $r u f a$, but is quite distinct from either. With respect to $\boldsymbol{M} \boldsymbol{H}$. $r u f a$, 
it is not improbable that it will prove to be only a phase of plumage of $M$. Mackinlayi, although in the type specimen the bill is stouter; the coloration in all the species of Macropygia I have met with varies considerably with age, and also frequently in the sexes.

\section{CAMPOPHAGID $\approx$.}

In Mr. Sharpe's Cat. of Bds., Vol. IV., I find our Campophaga Jardini of Gould, the Grancalus tenuirostris of Jard., placed in the genus Edoliisma, a genus created for the reception of $E$. milan by Jacquinot and Pucher, Voy. au Pôle Sud., Zool. Ois. p. 69., 1853. The genus Lalage, (Boie, Isis 1826, p. 973.) is used for all our small Campophagida. Under the genus Symmorphus, closely allied to Lalage, are two species, but neither descriptions agree with specimens from New Hebrides and New Caledonia in the Australian Museum. If Mr. Sharpe has taken his descriptions from really adult birds, then there is undoubtedly a third species yet to be described, but it is not improbable that Mr. Sharpe's description of the $\sigma^{\star}$ of S. novius is from an immature bird, and probably a $q$.

A specimen in the Museum Collection from the New Hebrides, an adult $\delta$, received in spirits, agrees with the description of $S$. leucopygius, $\delta$, except in the lores which are uniformly black, in the whole of the under surface the cheeks and under wing-coverts being white, and the rump of an ashy grey tint; adult males ( $S$. nevius?) from New Caledonia have the upper tail coverts white, and the head, neck, wings, back, and tail black, like the New Hebrides bird.

Mr. Sharpe has cleared up the mystery respecting Lalage leucomela, vel $L$. leucomelana, the Campophaga leucomela of Vigors and Horsfield.

I find as synonyms of this species Lanius karu, Less. and Garn. Campophaga karu, Gould, Bds. Aust. II. pl. 61 ; C. rufiventris, Gray 
C.polygrammica, Gray, and many others. Lalage humeralis, of Gould takes the older name of Lalage tricolor, the Ceblepyris tricolor of Swainson.

\section{MUSCICAPID王.}

\section{Petreca leggit, Sharpe.}

Under this name I find our common scarlet breasted robin, the Petroica multicolor of Swainson; (nec. Gmelin). It appears that the true Petroica multicolor of Gmelin, the Red bellied Flycatcher of Latham, is the Norfolk Island bird, Muscicapa erythrogaster of Latham, and Petroica erythrogastr a of Gould's Bds. Aust., fol. Vol. III., pl. 4.

\section{Petreeca ramsayi, Sharpe.}

A new species distinguished from Petraca goodenovii, (Vig. and Horsfield.) chiefly in having a scarlet instead of a black throat, it comes from Western Australia.

The name of Petroea bicolor must be retained for the Melanodryas cucullata of Gould, as Mr. Sharpe informs us, the description of $P$. cucullata " can never apply to P. bicolor."

\section{Gerygone.}

Mr. Sharpe divides the Gerygones into two genera; Gerygone, proper with the eigthth primary quill nearly equal to the second and much longer than the secondaries; the culmen exceeding in length the hind toe and claw, and Pseudogerygone, in which "the second primary quill is about equal to the secondaries, and the nostrils linear, shut in by a membrane, bristles scanty." Under Gerygone are G. albogularis and $G$.cinerascens, Sharpe, a new species from New Guinea and Victoria River, North Australia.

Under Pseudogerygone, are placed the Australian species $P$. culicivora, P. magnirostris, P. fusca, P. lavigaster, P. personata, $P$. chloronota and P. Mastersii, (Gerygone simplex, Masters) being a 
good species will also come under this division, with Gerygone insularis, Ramsay, frøm Lord Howe's Island.

Next comes an Australian new genus, Heteromias, created for the Pacilodryas? cinereifrons, Ramsay; this is a peculiar anomalousform allied to the Pachyceplataline and the Wood-robins, Pacilodryas.

Under Pacilodryas of Mr. Gould are placed the Australian species P.cerviniventris, P. superciliosa, Eupsaltria capito, of. Gould, and Eopsaltria nana of Ramsay. I cannot see the affinity of the two last with the genus Pacilodryas of Gould.

\section{Malurus Gouldi, Sharpe.}

Among the Maluride,-Australian Wrens,- - the only correction I find is that the Malurus longicaudus of Gould is not identical with the bird under that name mentioned by Temminck, (Man. d'Orn. 1820, p. Ixviii., see Sundeval Ann. and Mag. Nat. Hist. xviii., 1846. p. 252-3). The Tasmanian bird then, which also occurs in South Australia and Victoria, (the M. longicaudatus of Gould,) will be known as Malurus gouldi, Sharpe.

\section{Malurus dorsalis, Lewin.}

This is the Sylva dorsalis of Lewin, Bds. of New Holl., pl. 14. the Malurus brownii, of Vig. and Horsf., and the M. cruentatus of Gould.

A large series of specimens in the Australian Museum tend to prove that so far from them being three distinct species, they may all prove to belong to one and the same species. The N. S. W. M. melanocephalus are the lightest colored and have more of an orange tint in the crimson of the back; those from Rockingham Bay, and the Gulf of Carpentaria, are a little smaller, and of a darker tint, while those from Cape York, Port Essington, and Port Darwin, are the smallest and darkest, the wings are more or less brown in the younger birds, and become more or less black 
in the adults of those found north of Rockingham Bay. There are several species of New South Wales birds represented in North Australia by species differing only in intensity of coloring and size; for instance Pitta strepitans, Lopholaimus antarcticus, Carpophaga magnifica, Astur nova-hollandia, Malurus lamberti.

\section{RHIPIDURA.}

Under this genus the Tasmanian form of $R$. albiscapa, is very properly separated into a distinct species, under the name of Rhipidura saturata. It is probable however, that this name will not stand, having been used by Salvadori* already for $R$.maculipectus of Gray. I therefore propose to distinguish this bird under the name R. sharpei. $\quad$ R. saturata, Salvadori, is from Salvatti. $\dagger$

\section{RhIPIDURA tricolor, Vieillot.}

This proves to be the oldest of the numerous specific names given to our Rhip. motacilloides of Vig. and Horsf.; pl. 86 of Gould's Bds. of Australia.

a. R.motacilloides; b. R. picata, Gould; c. R. melanoleuca; are mentioned as varieties of this species.

\section{Myiagra rubecula, Lath.}

This is the Todus rubecula, of Latham, and the Myiagra plumbea of Vig. and Horsfield, but not the $M$. nidida of Gould, as stated by me in P.L.S., of N. S. Wales II., p. 182.

Under the genus Piezorhynchus, we find Gould's Monarcha trivirgata, which not being identical with the Monarcha (Drymophila) trivirgata of Temminck-must take the name of $M$. gouldi, Gray. The true M. trivirgata, Temm. is from Timor. $\mathrm{Mr}$. Sharpe unites Monarcha, or as he calls it Piezorhynchus gouldi, the New South Wales bird, with the Piezorhynchus albiventris, Gould, of Cape York; this is undoubtedly an error, as the birds from

* Ann. Mus. Civ. Gen. xii , p. 323. (1878).

† Since writing the above I find Mr. Sharpe has altered the name of this species to $R$. diemenensis. 
these localities are quite distinct and must retain the names given to them by Gray and Gould.

M. leucotis, Gould, is also placed in the Genus Piezorhynchus.

Under Monarcha, the Australian species described are Monarcha melanopsis, the Muscicapa melanopsis of Vieillot,- the M. carinata of Vig. and Horsf., and of Gould's Birds of Aust., Vol. II., pl. 95.

Unfortunately an error occurs here, the young bird of $M$. melanopsis being described as a female-in the adults both sexes are alike in plumage.

Monarcha canescens, Salvadori, a new species, said by D'Albertis, to come from Cape York, most probably a New Guinea bird, in coloration it is closely allied to the preceding.

It will be seen I have only referred to the Australian species in Mr. Sharpe's Catalogue, as being of most interest to ornithologists here; and taking into consideration the poor material he has had to work from, the greatest praise is due to Mr. Sharpe's ability and untiring energy. I am sure all ornithologists will congratulate Mr. Sharpe on the appearance of the fourth Volume of his work "Catalogue of Birds" and trust the learned author may have long life and health to complete so great an undertaking.

\section{On some Additional New Genera and Species of Amphipodous Crustaceans.}

By William A. Haswell, M.A., B.So.

[Plates XVIII.-XXIV.]

GROUP NORMALIA.

FAM. ORCHESTIDA.

Genus Allonchestes, Dana.

Allorchestes niger, $s p$. nov.

Eyes round. Superior antennæ nearly as long as the cephalon and the first two segments of the pereion ; first joint of peduncle 


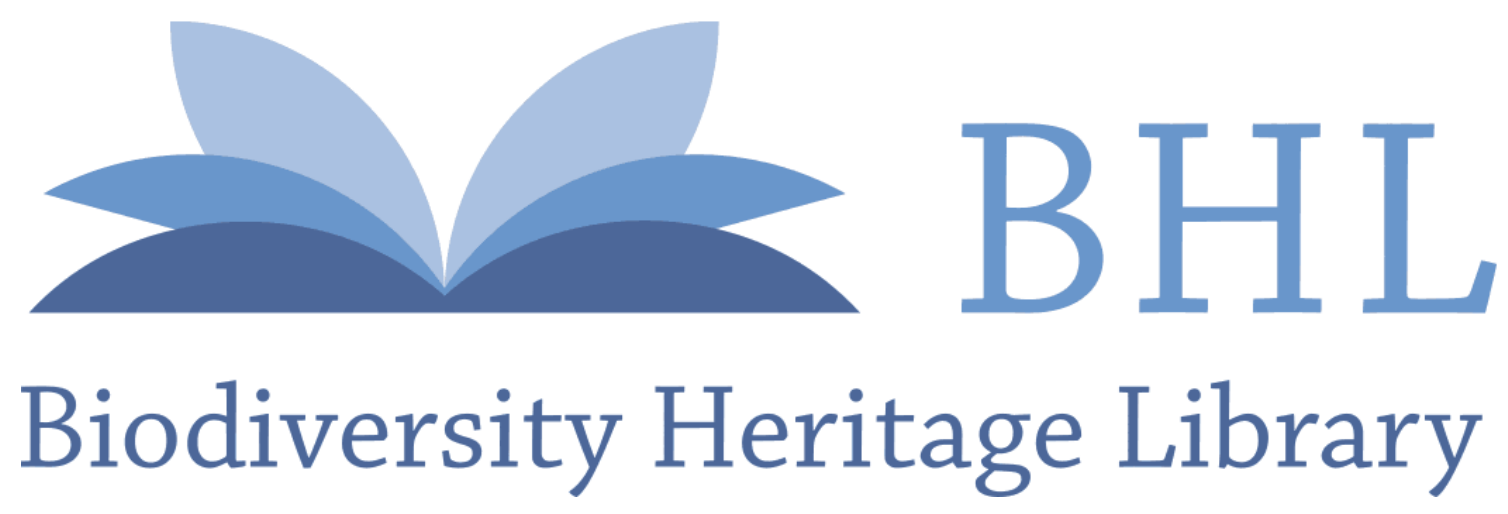

Ramsay, Edward Pearson. 1879. "Notes on some recently described birds from the Solomon Islands, with remarks on some Australian birds mentioned in Mr. R. B. Sharpe's Cat. of Bds., Vol. IV." Proceedings of the Linnean Society of New South Wales 4, 313-319. https://doi.org/10.5962/bhl.part.22853.

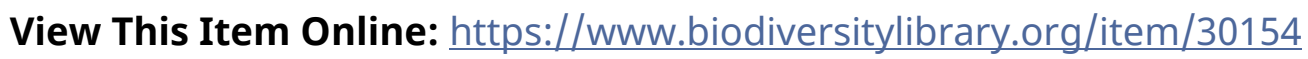

DOI: https://doi.org/10.5962/bhl.part.22853

Permalink: https://www.biodiversitylibrary.org/partpdf/22853

\section{Holding Institution}

MBLWHOI Library

\section{Sponsored by}

MBLWHOI Library

\section{Copyright \& Reuse}

Copyright Status: NOT_IN_COPYRIGHT

This document was created from content at the Biodiversity Heritage Library, the world's largest open access digital library for biodiversity literature and archives. Visit BHL at https://www.biodiversitylibrary.org. 